\title{
Güneydoğu Anadolu Bölgesi İllerinin CBS Kullanarak Hava Kalitesinin Mekânsal Değişiminin İncelenmesi (2007-2019)
}

\author{
Ercan Vural ${ }^{1, *}(\mathbb{D})$ \\ ${ }^{1}$ Harran Üniversitesi, Fen Edebiyat Fakültesi, Coğrafya Bölümü, 63100, Haliliye, Şanlıurfa. \\ Özet
}

Sanayi devrimiyle birlikte çevre sorunları çeşitlenmiş ve önemli ölçüde artış göstererek hem doğal hem de beşerî çevreyi etkilemiştir. Bu çevre sorunlarının en önemlileri arasında yer alan hava kirliliği geçmişte olduğu gibi günümüzde de ciddi bir sorun olmuştur. Güneydoğu Anadolu Bölgesi illerinde 2007-2019 yılları arasında hava kalitesi ve kirliliğine etki eden beşeri unsurların incelendiği bu çalı̧̧mada, kirlilik özellikle belirli illerde süreklilik göstermektedir. Bu sürekliliğe bağlı olarak amacımız bölge illerindeki hava kirliliğini tespit etmek ve bunlara çözüm önerisi sunabilmektir. Hava kirliliğinin mekânsal değişimini tespit etmek için Coğrafi Bilgi Sistemleri aracılığıyla IDW (Inverse Distance Weighting) analizi kullanılmıştır. Bu analiz yöntemiyle ölçümler arasında enterpolasyon sağlanmıștır. $\mathrm{SO}_{2}$ konsantrasyonun en fazla olduğu iller 2007'de Şanlıurfa ve Siirt, 2012'de Şırnak, 2017'de Şanlıurfa ve Siirt ve 2019'da da Şanliurfa'dır. PMı'de ise 2007'de Batman, 2012'de Gaziantep, Batman ve Siirt, 2017'de Şanluurfa ve 2019'da da Şırnak'ta ylllı ortalama konsantrasyon fazladır. Kirliliğin artmasinda en önemli beşeri unsurlar; şehirde yaşayan nüfus miktarl, konutlarda ve sanayide kullanılan yakıt türü ve kalitesi, sanayiye bağlı işletme sayısı ve araç sayısıdır. Bu manada insan să̆lığının bozulmasına hatta ölümlere neden olan hava kirliliğinde yerel ve ulusal yönetimlerin ciddi önlem alması gerekmektedir.

\section{$\underline{\text { Anahtar Sözcükler }}$}

Hava Kalitesi, Hava Kirliliği, Kükürt Dioksit, Partikül Madde, CBS

\section{Investigation of Spatial Change of Air Quality of Southeast Anatolia Region Provinces Using GIS (2007-2019)}

\begin{abstract}
With the industrial revolution, environmental problems have diversified and have increased significantly, affecting both the natural and the human environment. Air pollution, which is among the most important of these environmental problems, has been a serious problem today as it was in the past. In this study, which examines the human factors affecting air quality and pollution between 20072019 in the provinces of Southeast Anatolia Region, pollution shows continuity especially in certain provinces. Depending on this continuity, our aim is to detect air pollution in the provinces of the region and offer solutions to them. IDW (Inverse Distance Weighting) analysis was used through Geographic Information Systems to detect the spatial change of air pollution. With this analysis method, interpolation was provided between the measurements. The provinces with the highest $\mathrm{SO}_{2}$ concentration are Şanlurfa and Siirt in 2007, Şirnak in 2012, Şanliurfa and Siirt in 2017 and Şanluurfa in 2019. PM10 annual average concentration is high in Batman in 2007, Gaziantep, Batman and Siirt in 2012, Şanluurfa in 2017 and Şırnak in 2019. The number of population living in the city, the type and quality of fuel used in residences and industry, the number of industrial enterprises and the number of vehicles are among the important human factors affecting pollution. In this sense, local and national administrations should take serious measures in the air pollution that causes human health to deteriorate or even die.
\end{abstract}

$\underline{\text { Keywords }}$

Air Quality, Air Pollution, Sulfur Dioxide, Particulate Matter, GIS

\section{Giriş}

Sanayi devrimi ile kol gücü ortadan kaldırılmış ve bu gücün yerini makinalar almıştır. Böylece endüstri toplumları ortaya çıkmıştır. Endüstri toplumunun gelişmesiyle insanlar şehirlere göç etmeye başlamış, kalkınma ve yaşam standartlarını yükseltmek için de sürekli üretim yapma zorunluluğu içerisine girmiştir. Bu bakımdan çevresini yoğun olarak kullanmış ve çağımızın en büyük sorunlarından olan çevre ve insan sağlığı sorunlarının ortaya çıkmasına neden olmuştur. (İbret ve Aydınözü 2009). Temel de katı, sıvı ve gaz atıklarının sebep olduğu su, hava ve toprak kirliliği sorunları, modern dünyanın en önemli çevre sorunlarının temel taşlarını oluşturmaktadır (Batan 2013). 
Çevre sorunlarına, nüfus miktarı ve yoğunluğu (şehir-kır), sanayileşme, kentleşme (gecekondulaşma, plansız kentleşme vb.), yoğun olarak yapılan göçler vb. gibi faktörler etki etmektedir. Bu ve benzeri faktörlerin etkili olduğu çevre sorunları insan sağlığını, bitkileri, hayvanları, beşerî yapıları vb. birçok unsuru olumsuz düzeyde etkilemektedir.

Günümüzde, artan çevre sorunlarının başında gelen hava kirliliği, geleceğin çevre yapısını önemli ölçüde tehdit etmekte, ekolojik ve biyolojik tehlikelerle karşı karşıya bırakmaktadır. Hızla artan dünya nüfusuna paralel olarak, artan miktarda enerji kullanımı, sanayinin gelişimi ve kentleşmeyle başlayan hava kalitesinin düşmesi insan sağlığı başta olmak üzere diğer canlılar ve beşerî yapılar üzerinde olumsuz etki yaratmaktadır (Çiftçi vd. 2013). Hava kirliliği, toprak kirliliği gibi yerel veya su kirliliği gibi bölgesel sınırlarla kalmamaktadır (İbret ve Aydınözü 2009). Hava kirliliği global ölçekte hemen her ülkeyi tehdit eden bir sorundur. Araştırmacılar, insan yaşamı için en konforlu yerin temiz atmosferik çevre olduğunu belirtmişlerdir (Adıgüzel vd. 2019). Dünyada özellikle son 30-35 yılda hava kirliliği verilerinin düzenli olarak izlenmesine ve kirliliği azaltabilmek için ciddi anlamda mücadele edilmesine rağmen, özellikle büyük ve kalabalık şehirlerde kirlilik düzeyleri halen güvenli kabul edilmeyen seviyelerdedir. 1980'li yıllara kadar dünyada 1.3 milyar kişinin hava kalitesi standartlarının üstünde kirlilik içeren şehirlerde yaşadığı tespit edilmiştir (Cuci ve Polat 2015). 1980'lerde dünyada durum böyleyken günümüzde de küresel ölçekte hava kalitesi standart değerlerinin çok üstünde kirliliğe sahip olan ülkelerin sayısı ile bu kirlilikten etkilenen insan sayısı oldukça fazladır. Dünya Sağlı Örgütü’nün 2019 verilerinde her 10 kişiden 9'unun kirli hava soluduğu özellikle belirtilmiştir (ESRI 2020). Kirli hava solunmak insanlarda kalıcı hasarlarla hatta ölümlerle sonuçlanabilmektedir. Geçmişteki hava kirliliği nedeniyle, binlerce insan hayatını kaybetmiş, günümüzde de devam edecek şekilde hastalıklar artmış ve yaşam standartları önemli ölçüde düşmüştür (Alkan 2018). Kirli hava, basit göz burun rahatsızlıklarından zatürre ve verem gibi önemli akciğer hastalıklarına kadar pek çok hastalığa neden olabilmektedir (Tağıl 2007). Hava kirliliğinde özellikle kükürt oksitler $\left(\mathrm{SO}_{2}\right)$ ve partikül maddeler $\left(\mathrm{PM}_{10}\right)$ önemlidir. Havadaki kükürt oksitlerin en önemlisi kükürt dioksittir. $\mathrm{SO}_{2}$ suda çabuk çözünen bir gaz olduğundan kolay bir şekilde kan dolaşımına girebilmektedir (Çiçek vd. 2004). Hem kükürt oksitler hem de partikül maddeler kan dolaşımına girmelerinin yanı sıra akciğere yerleşerek önemli hastalıklara neden olmaktadırlar.

Türkiye'deki hava kirliliği olayları, 1950'li yıllardan itibaren başlayan sanayileşme trendleriyle, hızlı ve plansız kentleşmeye bağlı olarak ortaya çıkmış ve önüne geçilemez bir sorun haline gelmiştir. Son yıllarda gelişmekte olan ülkelerden biri olan Türkiye'de hava kirliliği değerleri ciddi boyutlara ulaşmıştır. Hava kirliliğinin resmi ölçüm sonuçları, ülke genelinde solunan havanın sağlığa zararlı olduğunu göstermektedir (Özşahin vd. 2016). Ülkemizdeki hava kirliliğinin başlıca kaynakları evsel ısınma, endüstriyel kullanım, karayolu trafiği, termik santraller ve diğer kaynaklar şeklindedir (Özbey vd. 2017). Özellikle büyük şehirlerde evsel ısınma ve karayolu trafiğine bağlı hava kirliliği görülürken, fonksiyonel olarak endüstriyel faaliyetlerin baskın olduğu şehirlerde ise endüstriyel kaynaklı hava kirliliği görülmektedir. Türkiye'de özellikle büyük şehirler başta olmak üzere şehirlerin büyük çoğunluğunda hava kirliliği problemi önemli bir konu olarak hem yerel hem de ulusal yöneticilerin sürekli gündeminde olan bir konudur (Atayeter 2005).

Türkiye'nin hemen her bölgesinde hava kirliliğgi sınır değerlerinin aşıldığı görülmektedir. Özellikle Güneydoğu Anadolu Bölgesi’nde Gaziantep, Şanlıurfa, Diyarbakır, Siirt ve Batman hava kirliliğinin en yüksek seviyede olduğu iller arasında yer almaktadır. Güneydoğu Anadolu Bölgesi, konumu nedeniyle Suriye ve Arabistan çöllerine yakın olması ve çöl bölgelerinin etkisini önleyecek topografik engellerin bulunmaması nedeniyle çöl kaynaklı tozlardan yılın belirli dönemlerinde etkilenmektedir. Fakat bölgenin kuzeyinde sıra halinde uzanan Güneydoğu Torosların varlığı çöl tozlarının etki alanını sınırlamıştır (Şengün ve Kıranşan 2012). Bu kapsamda, Güneydoğu Anadolu Bölgesi’nde endüstriyel, evsel, trafik kaynaklı hava kirliliğinin görülmesinin yanı sıra bölgenin yakın çevresinde bulunan çöllerden gelen tozlar da bölgede hava kirliliğine ve çamur yağışlarına neden olmaktadır.

Bu çalışmanın amacı, Güneydoğu Anadolu Bölgesi özelinde hava kirliliğinin 2007-2019 yılları arasında mekânsal değişimini ortaya koymak ve ortaya çıkan sonuçlara çözüm önerileri sunmaktır. Hava kalitesi yaşam ilişkisi çerçevesinde konu irdelenirken, hava kirliliğine kaynak olabilecek belli başlı etkenlere ki bunlar; yıllara göre nüfus miktarı (şehir-kır) ve yoğunluğu, araç sayısı, sanayi gelişimi, konut sayısı, konutlarda ve endüstriyel tesislerde kullanılan yakıt türü ve miktarı ve bunlara bağlı sonuç olarak da ortaya çıkan solunum hastalıklarının periyodik seyri göz önünde bulundurulmuştur.

\section{Materyal ve Metot}

Hava kirliliğinde kaynağa bağlı olarak değişiklik gösteren birçok kirletici unsur bulunmaktadır. Bu çalışmada Çevre Şehircilik Bakanlığı ve TÜiK'in 2007-2019 yılları arasında Güneydoğu Anadolu Bölgesi illerine (Adıyaman, Batman, Diyarbakır, Gaziantep, Kilis, Mardin, Siirt, Şanlıurfa, Şırnak) ait $\mathrm{SO}_{2}$ ve $\mathrm{PM}_{10}$ değerleri incelenmiştir. 9 ile ait istasyon verileri otomatik olarak ölçüm yapmaktadır ve anlık olarak "Ulusal Hava Kalitesi İzleme Ağı"ndan (http://index.havaizleme.gov.tr/Report/Station) takibi sağlanabilmektedir. İlgili bakanlık ve kurumlardan elde edilen verilerin yıllık ortalaması göz önünde bulundurulmuştur. Ayrıca kükürt dioksit ve partikül madde miktarlarında 2019 yılından itibaren geçerli olan sınır değerlere göre değerlendirme yapılmıştır. Hesaplanan yıllık ortalamalar ArcGIS 10.4 programında IDW (Inverse Distance Weighting - Ters Mesafe Ağırlıklı) enterpolasyon yöntemiyle haritalandırılmıştır. Verilerin ağırlıklı ortalamasını temel alan bir enterpolasyon yöntemidir. Yumuşatılmış ve hızlı sonuç alınması gereken durumlarda kullanılan bir yöntem olan IDW matematiksel işlemler ile sonuç üretmektedir (Toros vd. 2018). 
Ters Mesafe Ağırlıklı enterpolasyon yöntemi, bir dizi numune noktasının doğrusal ağırlıklı bir kombinasyonunu kullanarak hücre değerlerini belirler. Ağırlık, ters mesafenin bir fonksiyonudur. Enterpolasyon yapılan yüzey, konuma bağlı bir değişken olmalıdır. Bu yöntem, eşlenen değişkenin, örneklenen konumundan olan mesafe ile etki olarak azaldığını varsayar. Örnek vermek gerekirse, bir perakende satış alanı analizi için tüketici satın alma gücünün bir yüzeyini enterpole ederken, daha uzak bir konumun satın alma gücünün daha az etkisi olacaktır, çünkü insanların eve daha yakın alışveriş yapma olasılığı daha yüksektir" (ÇMO 2019).

\section{Güneydoğu Anadolu Bölgesi’nde Hava Kirliliğini Etkileyen Bazı Beşerî Faktörler}

\subsection{Nüfus Artış Hızı ve Yoğunluğu}

Hava kirliliği, sosyal olaylar, ekonomik etkinlikler ve doğal olaylar sonucunda oluşan is, duman, toz, gaz, buhar vb. kirletici unsurların havanın doğal bileşimi (Şengün ve Kıranşan 2012) içinde aşırı miktarda barınan ve tepkimeye girerek yapıyı bozan ve sonucunda da insana ve doğal ortama zarar veren atmosfer içinde bulunması gerekenden fazla bulunan ve atmosfere yabancı olan gazların tümünün oluşturduğu olaya denmektedir. Bu manada özellikle sosyal ve ekonomik yapı içinde demografik miktar çok önemlidir. Nüfus miktarı fazla olan şehirlerde hava kirliliği daha fazla görülmektedir. Hava kirliliği günümüz kentsel bir olgudur. Büyük doğal felaketler gerçeklemediği takdirde kırsal alanlarda hava kirliliğinden söz edilmesi çok olası değildir (Demirarslan ve Akınc1 2018). Bu nedenle özellikle şehirdeki nüfusun yıllara göre azalıp artması hava kirliliğinin de oranını belirlemektedir. Nüfusu fazla olan şehirlerde konut sayısı artacak, daha fazla yakıta ihtiyaç duyulacak ve böylece atmosfere salınan kirletici unsurlarda artış meydana gelecektir. Güneydoğu Anadolu Bölgesi’nin hava kalitesini ve kirliliğini etkileyen en önemli faktörlerin başında hızlı nüfuslanma gelmektedir (Şengün ve Kıranşan 2012). Bir bölgede doğal nüfus artışın yanı sıra işsizlik, düşük maaş, zorlu çalışma koşulları, ekonomik beklentilerin ihtiyacı karşılamaması, yaşam koşullarındaki zorluğa bağlı olarak oluşan (Sertkaya Doğan 2015) göç alış-verişi de hava kirliliğinin artmasına veya azalmasına neden olabilmektedir. Güneydoğu Anadolu Bölgesi illerinin 2007-2019 yılları arası şehir ve kır nüfuslarına bakıldığında; tüm illerin şehir nüfus miktarlarında artış görülmektedir. Kır nüfuslarında ise dalgalanmalar görülmektedir. Fakat hava kirliliğinin yaşanması için özellikle şehirde yaşayan nüfusun önemli etkisi bulunmaktadır. Şekil 1'de belirtildiği gibi 2007'de Adıyaman şehir nüfusu 329.060 iken 2019'da \%31,21 artarak 431.758'e, Batman şehir nüfusu 342.452 iken, 2019'da \%43.76 oranında artarak 492.312'ye, Diyarbakır ilinin toplam nüfusu 2007 'de 1.460 .717 iken 2019 'da \%20.24 artarak 1.756.353'e, Gaziantep ilinin toplam nüfusu 2007'de 1.560.023 iken, 2019'da \%32.65 artarak 2.069.364'e, Kilis şehir nüfusu 2007'de 82.419 iken, 2019'da \%31.25 artarak 108.172'ye, Mardin ilinin toplam nüfusu 2007'de 745.778 iken, 2019'da \%12.47 artarak 838.778'e, Siirt şehir nüfusu 2007 'de 173.770 iken 2019 'da \% 25.77 artarak 218.5563'e, Şanlıurfa ilinin toplam nüfusu 2007'de 1.523.099 iken, 2019 'da \%36.14 artarak 2.073.614'e ve son olarak da Şırnak şehir nüfusu 2007'de 256.352 iken, 2019'da \%30.93 artarak 335.652'ye ulaşmıştır. Bu çerçevede 2007 yılından 2019 yılına kadar olan süreçte en fazla nüfuslanan yer 550.515 kişi ile Şanlıurfa olmuştur. En az nüfuslanan yer ise 25.753 ile Kilis olmuştur. 2007'den 2019'a kadar olan sürede Kilis, Şırnak ve Siirt dışında Adıyaman, Batman, Diyarbakır, Gaziantep ve Mardin'de 100.000'in üzerinde nüfus artışı meydana gelmiştir.

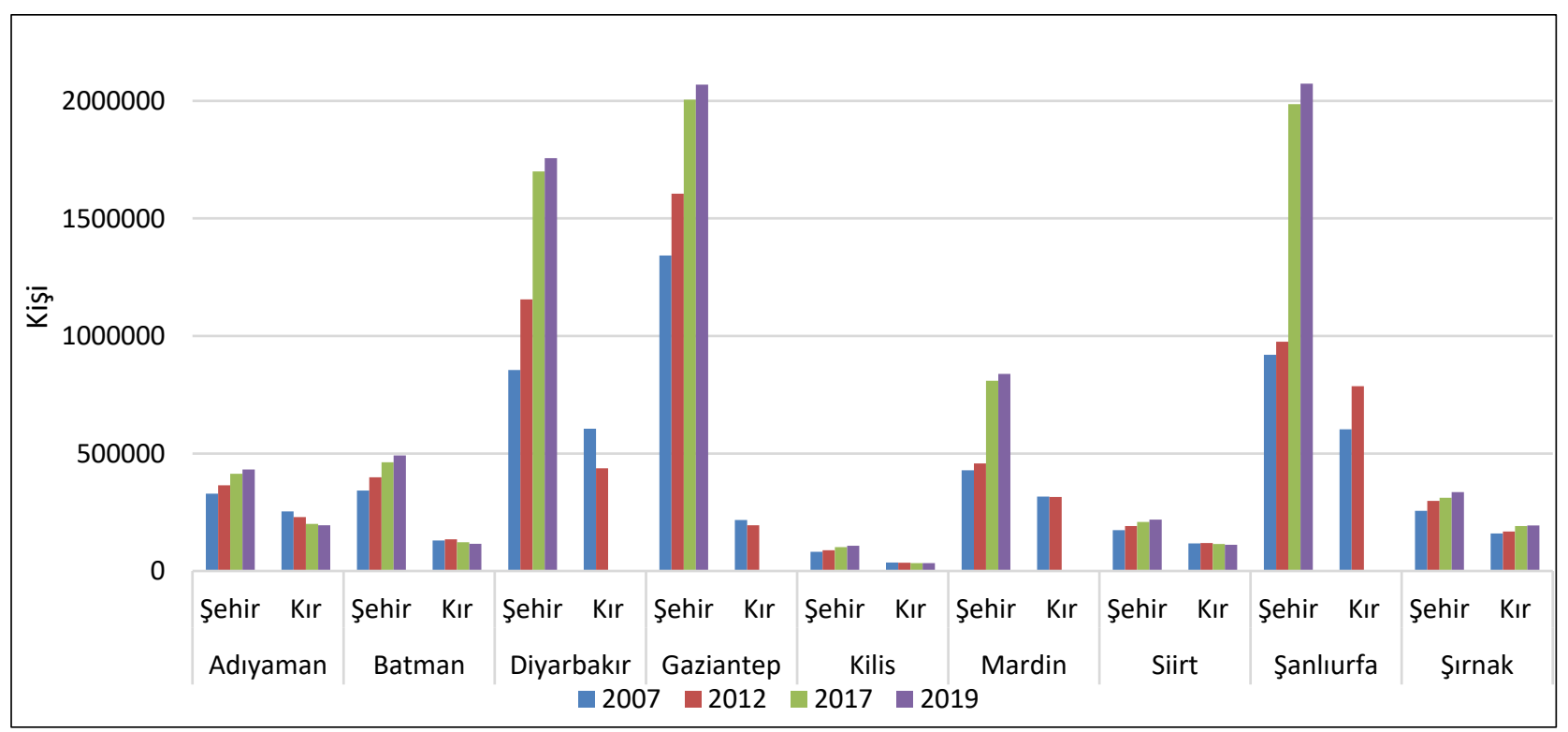

Şekil 1: Güneydoğu Anadolu Bölgesi illerinin şehir ve kır nüfusu miktarı (2007-2019) (TÜíK 2020a) 
Hızlı nüfus artışının hava kirliliği üzerindeki bir başka etkisi de nüfusun alansal yoğunluğu sayesinde gerçekleşmektedir (Özşahin vd. 2016). Bu bakımdan tablo 1'de görüldüğü gibi bölgede yer alan tüm illerin 2007'den 2019'a kadar olan süreçte nüfus yoğunluklarında artış meydana gelmiştir. Nüfus yoğunluğu en fazla Gaziantep'te görülmektedir. En az nüfus yoğunluğu artışı ise Adıyaman'da görülmektedir.

Tablo 1: Güneydoğu Bölgesi illeri aritmetik nüfus yoğunluğu (km²/kişi) (2007-2019)

\begin{tabular}{|l|r|r|r|r|}
\hline İller & \multicolumn{1}{|c|}{$\mathbf{2 0 0 7}$} & $\mathbf{2 0 1 2}$ & $\mathbf{2 0 1 7}$ & $\mathbf{2 0 1 9}$ \\
\hline Adıyaman & 74 & 75 & 78 & 79 \\
\hline Batman & 101 & 114 & 125 & 130 \\
\hline Diyarbakır & 95 & 103 & 110 & 114 \\
\hline Gaziantep & 204 & 235 & 262 & 270 \\
\hline Kilis & 72 & 75 & 83 & 86 \\
\hline Mardin & 83 & 86 & 91 & 94 \\
\hline Siirt & 53 & 57 & 60 & 61 \\
\hline Şanlıurfa & 81 & 94 & 106 & 111 \\
\hline Şırnak & 58 & 65 & 70 & 73 \\
\hline
\end{tabular}

Özellikle Batman, Diyarbakır, Gaziantep ve Şanlıurfa'da nüfus yoğunluğu 100'ün üzerindedir. Bu bakımdan hava kirliliği bu illerde etkisini daha fazla göstermektedir. Doğal ve göç yoluyla artan nüfus miktarı ve yoğunluğun artması mevcut konut sayısının artmasına veya boş konutların dolmasına ve daha fazla yakıt ve araç kullanımına neden olabilmektedir.

\subsection{Konutlarda Kullanılan Yakıt Türü ve Miktarı}

Hava kirliliği aşırı kullanılan fosil yakıtlar nedeniyle gelişen dünyanın en büyük problemlerinden biridir (Tağıl 2007). Bu problemlerin en fazla görüldüğü yerler şehirlerdir. Fosil yakıtlar hem konutlarda 1sınma amacıyla hem de sanayi de enerji olarak kullanılmaktadır. Sanayi de fosil yakıtların kullanımı yıl boyunca devam ederken, konutlarda sadece özellikle hava sıcaklığının düşmesiyle birlikte kullanılmaktadır. Fosil yakıtların kalitesinin ve miktarının Güneydoğu Anadolu Bölgesi'nde hava kirliliğinin yaşanmasında önemli bir yeri vardır. Bu çerçevede İl Çevre Durum Raporlarından elde edilen 2010-2018 yılları arası konut ve sanayide kullanılan yakıt türü ve miktarı hava kirliliğinin yaşanmasındaki etkiyi açıklar niteliktedir.

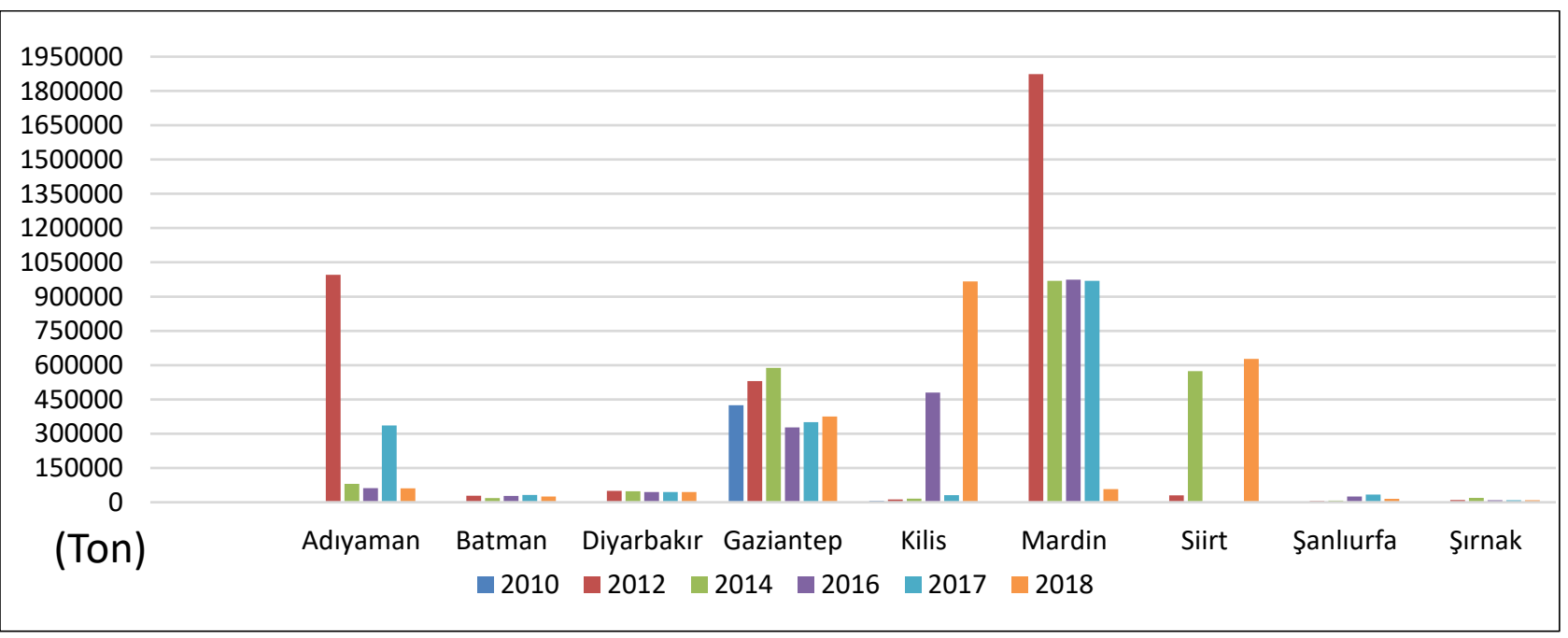

Şekil 2: Güneydoğu Anadolu Bölgesi illeri konutlarda kömür kullanımı (ton) (ÇŞB 2020) 
Şekil 2'de görüldüğü gibi bölgede konutlarda ısınma için özellikle yerli ve ithal kömür kullanımı oldukça yaygındır. Konutların 1sıtılmasında kömür kullanımı havada hem kükürt dioksit kirliliğine hem de is, kurum gibi partikül madde kirliliğine neden olmaktadır. Konutların ısınmasında Gaziantep, Mardin, Siirt, Şanlıurfa, Adıyaman ve Kilis illerinde kömür kullanımı oldukça fazladır. Konutlarda en fazla kömür kullanımı Mardin'de görülürken, en az kömür ise Şırnak’ta kullanılmaktadır.

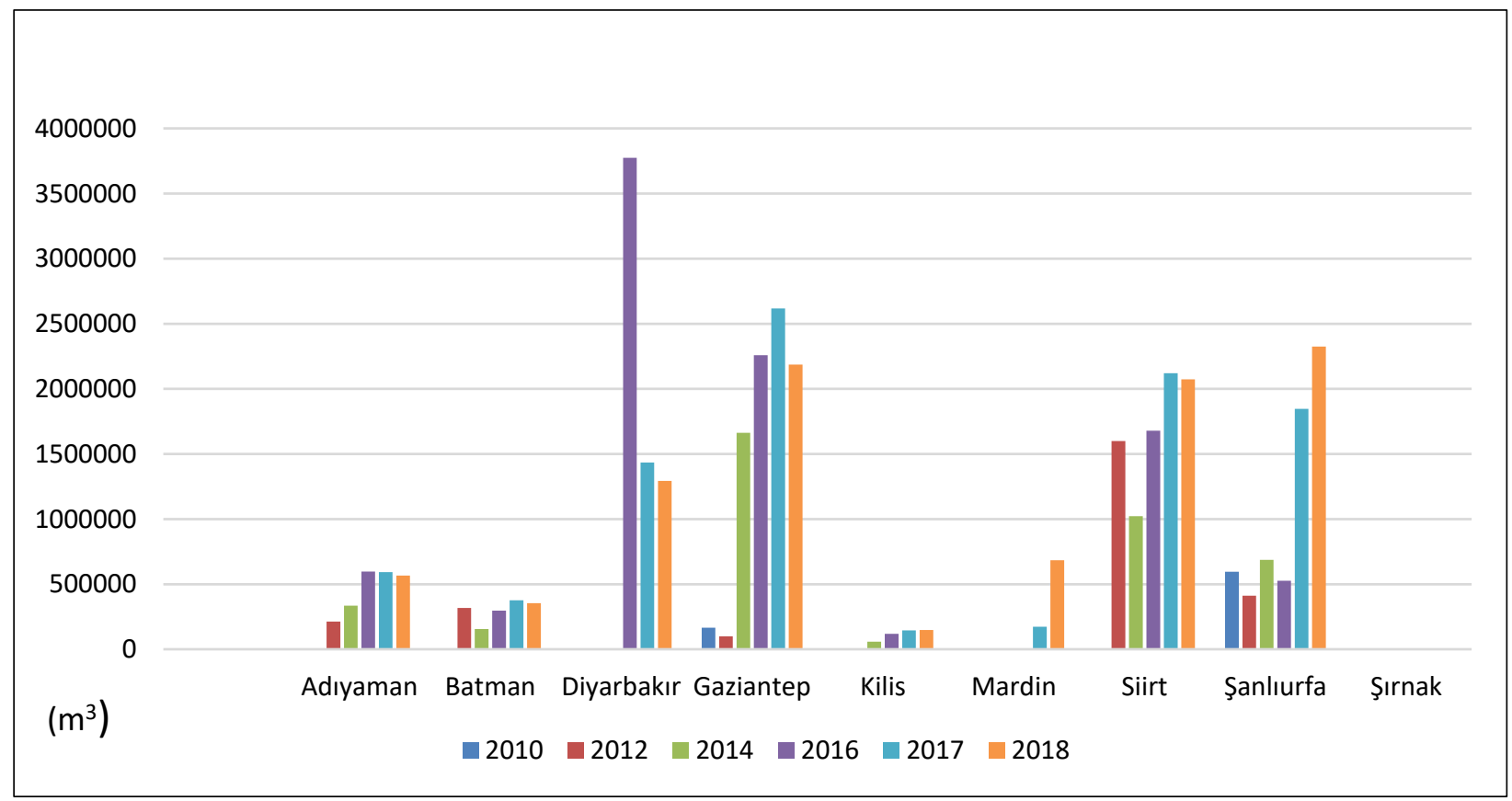

*Şırnak iline 2018 yılında doğalgaz verilmeye başlanmıştır. (GAZBİR 2018 Yılı Sektör Raporu)

Şekil 3: Güneydoğu Anadolu Bölgesi illeri konutlarda doğalgaz kullanımı (m³) (ÇŞB 2020)

Güneydoğu Anadolu Bölgesi illerinde yer alan konutlarda 1sıtma amaçlı olarak doğalgaz kullanımı oldukça yaygındır. Şekil 3'te Şırnak dışındaki tüm illerde doğalgaz kullanıldığı görülmektedir. En fazla doğalgaz kullanımı olan iller Adıyaman, Batman, Diyarbakır, Gaziantep, Siirt ve Şanlıurfa'dır. Kilis ve Mardin’de ise nispeten fazladır.

\subsection{Sanayi Gelişimi, Kullanılan Yakıt Türü ve Miktarı}

Türkiye'de hava kalitesini düşüren önemli sebepler arasında kentleşme ve sanayileşme yer almaktadır. Çünkü ülkemizde kentleşme düzeyindeki artış ve sanayileşme girişimlerinin yoğunlaştı̆ğ dönemde hava kirliliğinde önemli düzeyde artışların olduğu görülmüştür (Sümer Çakır 2014). Sanayide enerji üretme kapsamında kullanılan yakıtlar fiziki ve beşerî ortamın kirlenmesine neden olmaktadır. Enerji insan yaşamında her zaman yarar sağlamaktadır. Ancak bunun yanı sıra enerji ve enerjiye bağlı olarak ortaya çıkan çevre sorunları da artış göstermektedir (Doğan 2011). Özellikle sanayi merkezlerinde bu kaynaklara endüstri emisyonlarından kaynaklanan kirleticiler de eklenmektedir (Garipağaoğlu 2003). Sanayileşme, hava kalitesini düşüren önemli kirleticilerden olan $\mathrm{SO}_{2}$ ve PM 'nin ortaya çıkmasına neden olmaktadır. (Şengün ve Kıranşan 2012). Yayılan bu gazlar ve tozlar özellikle şehirlerin üzerinde katman şeklinde kirlilik oluşturmaktadır. 


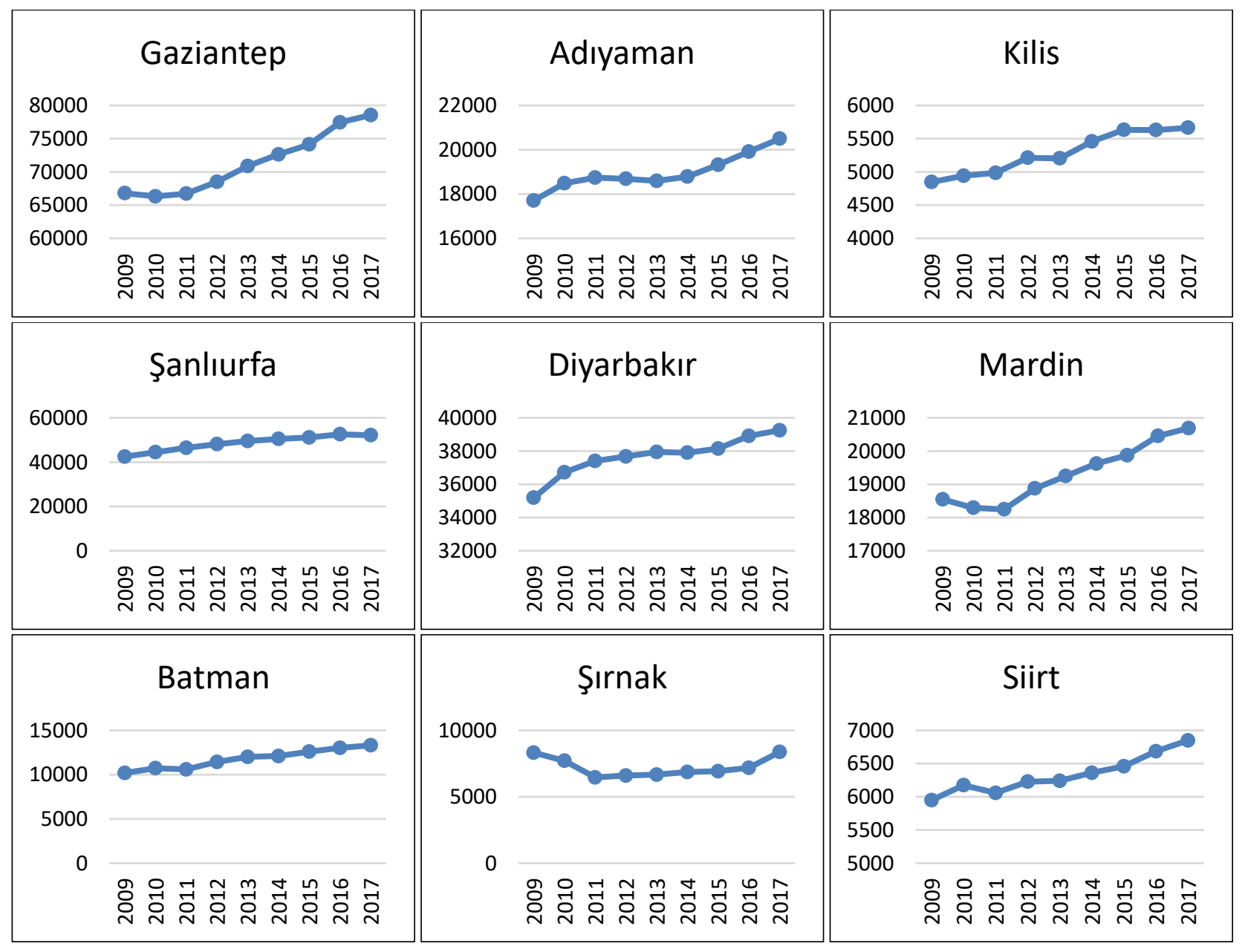

Şekil 4: Güneydoğu Anadolu Bölgesi illerinin sanayi işletmeleri sayısı (2009-2017) (STB 2020)

Güneydoğu Anadolu Bölgesi illerinde de sanayi bakımından önde gelen iller başta olmak üzere ciddi ölçekte kirlilik görülmektedir. 2009'dan 2017 yılına kadar olan süreçte tüm illerde sanayiye bağlı işletme sayısında artışın olduğu görülmektedir. Şekil 4 incelendiğinde en fazla Gaziantep’te görülen artış en az ise Kilis'te görülmektedir. Bu artışa bağlı olarak da hava kirliliği özellikle sanayisi gelişmiş illerde yoğun şekilde görülmektedir. Bu kirlilik Gaziantep başta olmak üzere, Şanlıurfa, Diyarbakır ve Adıyaman'da konutlarda ısıtma ve motorlu taşıtlara ek olarak sanayiye bağlı da görülebilmektedir.
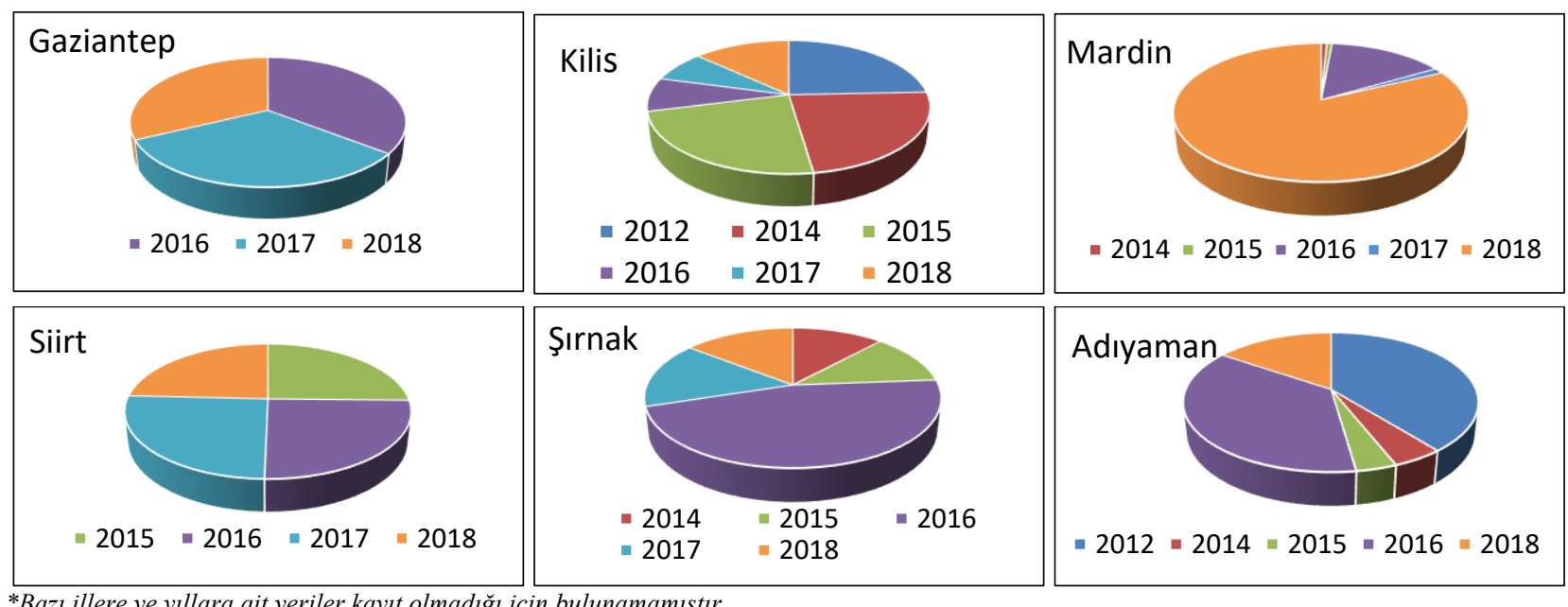

Şekil 5: Güneydoğu Anadolu Bölgesi illeri sanayisinde kullanılan kömürün yıllara göre değişimi (ÇŞB 2020) 
Hava kirliliğinin artmasında ve etkilemesinde yakıt türünün çok büyük etkisi bulunmaktadır. Bu bakımdan özellikle sürekli üretim halinde olan sanayilerin kömür veya doğalgaz kullanımları hava kirliliğini büyük ölçüde etkilemektedir. 2012-2018 yılları arası sanayide kullanılan yakıt türlerini gösteren şekil 5'e bakıldığında kömürün en fazla 2018'de Mardin'de ve 2016'de da Şırnak'ta kullanıldığı görülmektedir. Diğer illerde ise kömür kullanımının oldukça düşük seviyede olduğu görülmektedir. Sanayide doğalgaz ise en fazla Gaziantep'te kullanılırken, sonrasında da Şanlıurfa'da kullanılmaktadır. Batman, Adıyaman ve Siirt’te de düşük miktarlarda doğalgaz kullanılmakta iken Diyarbakır ile ilgili veriye ulaşılamamıştır.

\subsection{Araç Sayısı}

Bir bölgedeki hava kalitesini etkileyen en önemli faktörlerden bir diğeri de araç sayısı veya trafik yoğunluğudur. Araç sayısının yanı sıra araçların dizel, benzinli veya LPG'li olması da hava kalitesini etkileyen unsurlar arasında yer alır. Ayrıca bir bölgedeki toz yoğunluğu olarak ifade edilen PM $_{10}$ 'a neden olan kaynaklar arasında maden ve kömür ocaklarını, inşaat sahalarının yanı sıra trafikteki araçlarda yer almaktadır (Özbeyaz vd. 2016). Trafikteki motorlu taşıtların hareket etmelerini sağlayan fosil yakıtlar petrol ve gazların yanması sırasında çıkan gazlar hava kirlenmesinin önemli nedenlerinden biridir (Çiftçi vd. 2013).

Güneydoğu Anadolu Bölgesi illerinin 2007'den 2018'e kadar olan süredeki yıllık araç değişim miktarı hava kirlilik seviyesinin düşmesine veya yükselmesine neden olabilecek önemli faktörler arasında yer almaktadır. Şekil 6 incelendiğinde bölgede en fazla araç Gaziantep’te, en az araç ise Şırnak’ta bulunmaktadır. Nüfus miktarı ile araç miktarında paralel olarak artış görülmektedir (Vural, 2019). Bu artış da Gaziantep’ten sonra Şanlıurfa, Adıyaman ve Diyarbakır gelmektedir. Araç sayısının fazla olması egzozlarından çıkan gazların insana, hayvanlara, bitkilere ve beşerî yapıya önemli ölçüde zarar vermesine neden olmaktadır.

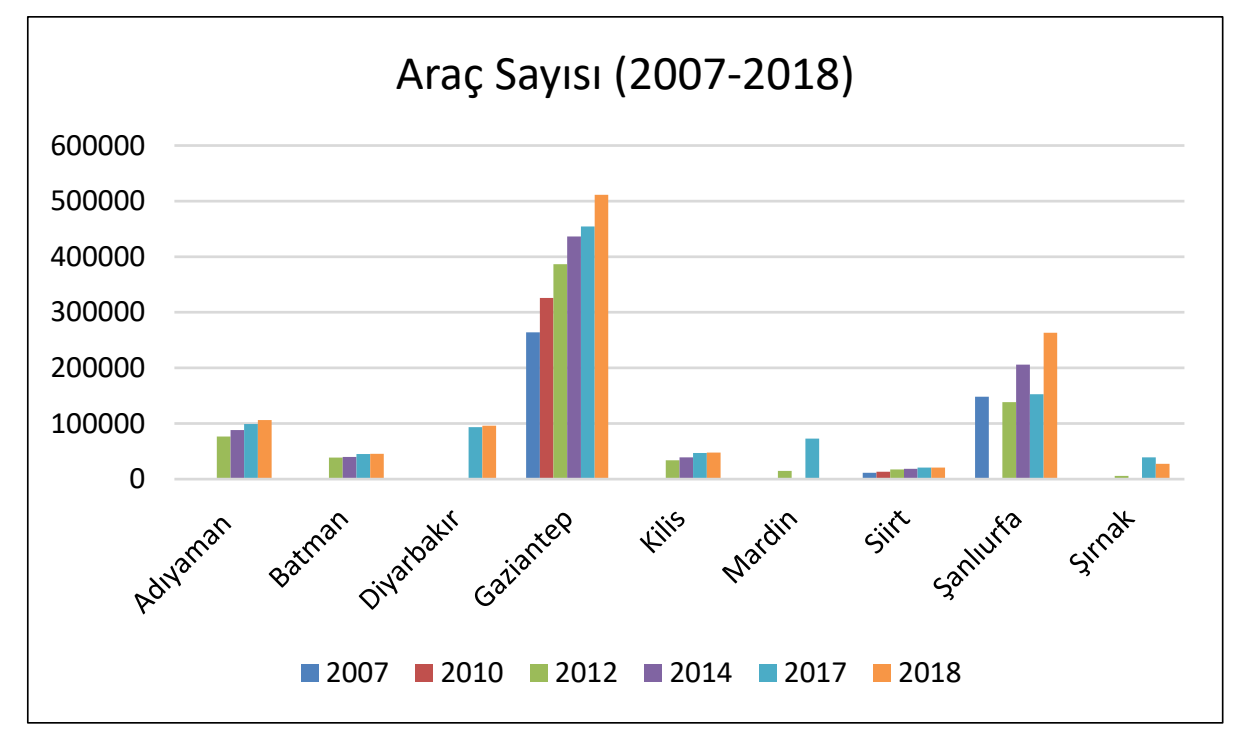

Şekil 6: Güneydoğu Anadolu Bölgesi illerinde araç sayısı (2007-2018) (ÇŞB 2020)

\section{Bulgular}

Hava, tıpkı su ve toprak gibi kirlenebilen bir ortamdır (Bayat 2011). Bu nedenle atmosfer temizliği ülke, bölge ve yerel ölçekte oldukça önemlidir. 2007-2019 yılları arasında Güneydoğu Anadolu Bölgesi illerinin $\mathrm{SO}_{2}$ ve $\mathrm{PM}_{10}$ yıllık değişimlerinin incelendiği bu çalışmada yıllara göre kirli havanın yer değiştirdiği görülmektedir. $\mathrm{SO}_{2}$ ve $\mathrm{PM}_{10}$ 'nun hava kirliliği oluşturma eşiği ülkemizde $\mathrm{SO}_{2}$ için $20 \mu \mathrm{g} / \mathrm{m}^{3} \quad$ (mikrogram/metreküp), $\mathrm{PM}_{10} \quad$ için $\quad \mathrm{de} \quad 40 \quad \mu \mathrm{g} / \mathrm{m}^{3}$ (mikrogram/metreküp)'dür. Özellikle endüstri de üretim, konutlarda 1sıtma, motorlu taşıtlarda da yanma sonucu ortaya çıkan kirliliğe ek olarak “ülkemizde ölçülen kum ve toz firtınalarının büyük bölümünün Güneydoğu Anadolu Bölgesi’nde ölçülmesi” (Dündar vd. 2013), sahada toz ve kum firtınalarının belirli dönemlerde arttığını ve çevre çöl alanlarından gelen toz parçacıklarının da atmosferi kirleten bir diğer kaynağı oluşturduğu görülmektedir.

Şekil 7'de gösterildiği gibi 2007'de yıllık SO 2 miktarının iki katına çıktığı yerler Şanlıurfa ve Siirt'tir. Özellikle her iki alanda da kirliliğin bu denli fazla olması; kullanılan yakıt, endüstriyel kullanım ve trafikteki araç sayısı ile açıklanabilmektedir. Şanlıurfa' da hava kirliliğinin fazla olmasının nedenleri arasında, kalitesiz ve yoğun kömür kullanımı ve trafikteki araç sayısının fazla olması yer almaktadır. $\mathrm{SO}_{2}$ miktar bakımından en az kirli olan yer ise Şırnak'tır. 2007 yılında Şırnak'ın $\mathrm{SO}_{2}$ bakımından atmosferinin temiz olması araç sayısının azlığına, sanayi üretiminin nispeten diğer illere göre az olması ile yakından ilgilidir. 

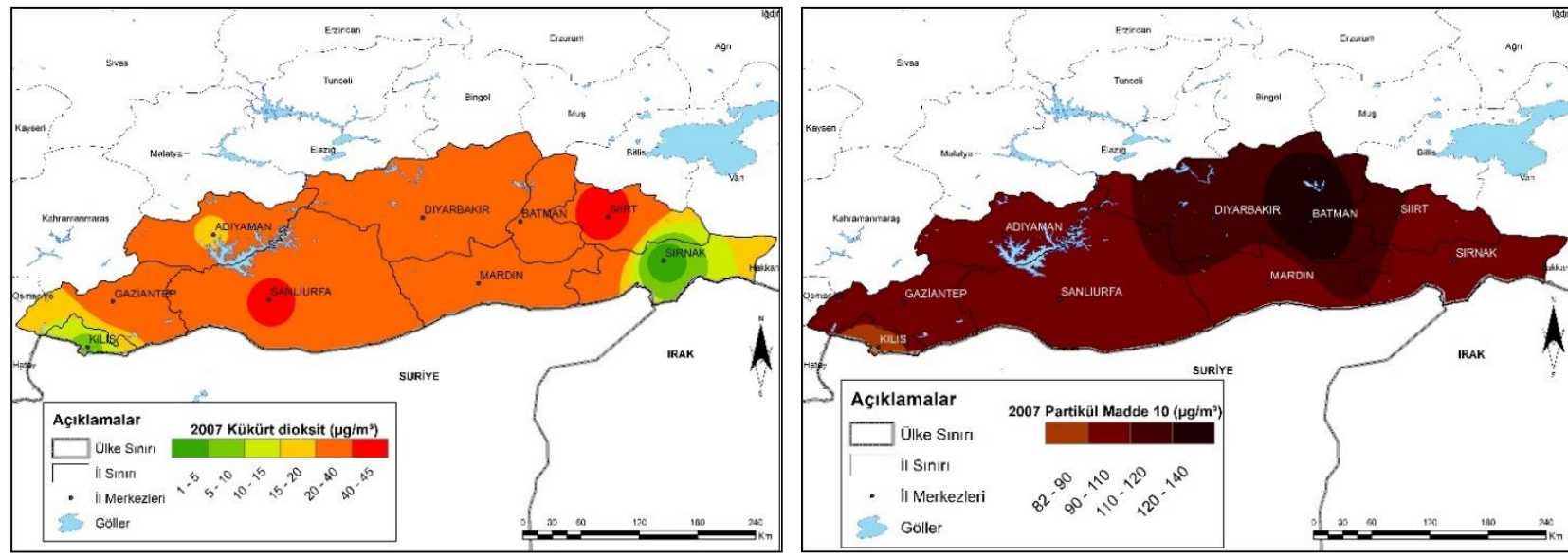

Şekil 7: (a) Güneydoğu Anadolu Bölgesi illerinin yıllık SO $S_{2}$ değeri ( $\left.\mu g / m 3\right)$ ve (b) PM10 değeri ( $\left.\mu g / m 3\right)$ (2007)

Bölgede $\mathrm{PM}_{10}$ 'nun yıllık değerlerinde ise ciddi ölçüde kirlilik görülmektedir. Şekil 7'de de gösterildiği gibi $\mathrm{PM}_{10}$ bakımından havası en kirli olan yer Batman'dır. Batman'da $\mathrm{PM}_{10}$ miktarı yaklaşık olarak $140 \mu \mathrm{g} / \mathrm{m}^{3}$ 'e çıkmıştır ki sınır değer $40 \mu \mathrm{g} / \mathrm{m}^{3}$ 'dür. Batman'da konutlar da ve sanayi de kömür kullanımının yaygın olması ve araç sayısının nispeten fazla olması gibi beşerî nedenlerin yanı sıra özellikle yakın çevrede bulunan çöllerden gelen toz parçacıkları da başta insan sağlığı olmak üzere hem beşerî hem de fiziki çevreyi etkilemektedir. Hemen tüm illerde $\mathrm{PM}_{10}$ miktarında sınır değerin aşıldığı görülmektedir.

Şekil 8'de gösterildiği gibi 2012 'de en fazla $\mathrm{SO}_{2}$ kirleticisinin görüldüğü yer Şırnak olmuştur. Şırnak’ta bu tür kirletici unsurun görülmesindeki başlıca etmenler, 2012 yılında nüfus yoğunluğunda, şehir nüfusunda ve sanayiye bağlı işletmede bir önceki yıla göre büyük oranda artış gibi nedenlerle özellikle kış aylarında $\mathrm{SO}_{2}$ kirleticisinin yaygın görülmesi yıllık miktarı arttırmıştır. Bu nedenle Şırnak ve yakın çevresinde $\mathrm{SO}_{2}$ 'ye bağlı kirlilik görülmüştür. Ayrıca bu dönemde hemen tüm illerde $\mathrm{SO}_{2}$ miktarında artışın olduğu görülmektedir. Bölgede 2012'deki $\mathrm{SO}_{2}$ değeri 2007'deki değerden yaklaşık olarak 4 kat artmıştır.
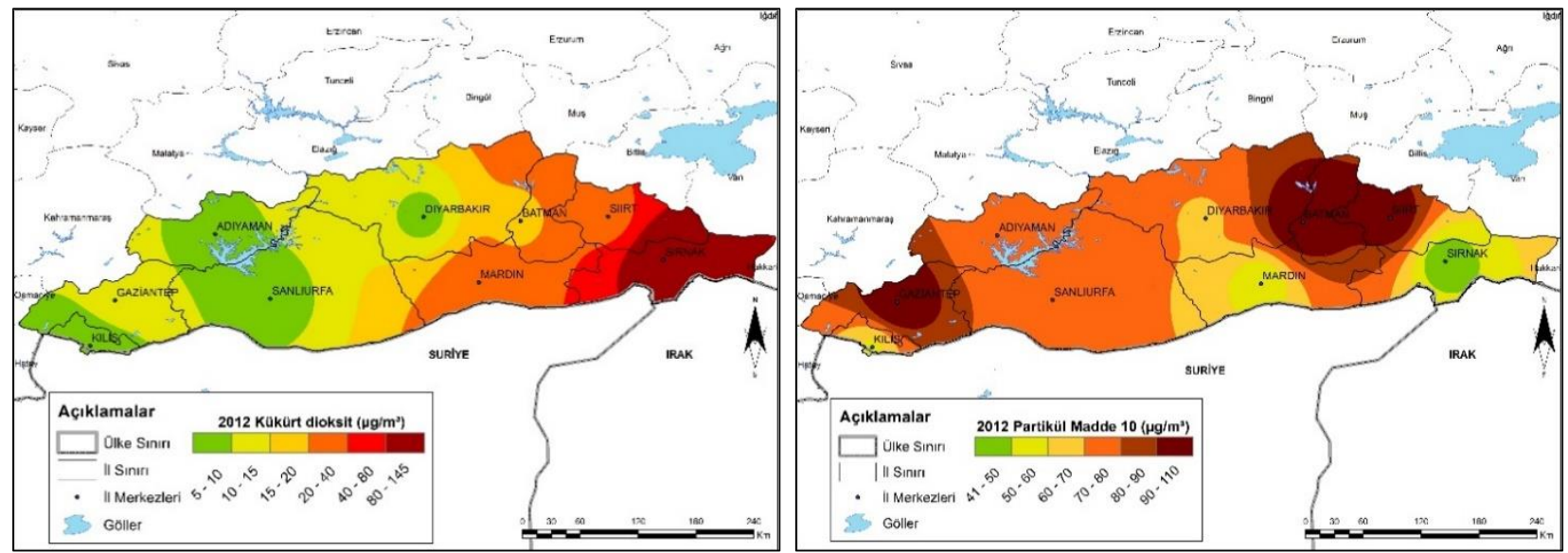

Şekil 8: (a) Güneydoğu Anadolu Bölgesi illerinin yıllık SO ${ }_{2}$ değeri ( $\left.\mu g / m 3\right)$ ve (b) PM10 değeri ( $\left.\mu g / m 3\right)$ (2012)

2012'de $\mathrm{PM}_{10}$ yıllık değerlerinde ise bölgede tüm illerde sınır değerin aşıldığı görülmektedir. Özellikle Batman, Gaziantep, Siirt ve yakın çevrelerinde yoğun bir şekilde $\mathrm{PM}_{10}$ kirliliği görülmektedir (Şekil 8). Bu kirlilik de konutlarda ısınma amacıyla kömür kullanımı, sanayi de kömür veya fuel-oil kullanımı ve ayrıca çöl tozları büyük rol oynamaktadır. Ayrıca bölgedeki en fazla aracın Gaziantep'te olması hem ilin hem de bölgenin hava kalitesinin düşmesine neden olmaktadır.

Şekil 9 incelendiğinde 2017 'de, bölgede $\mathrm{SO}_{2}$ miktarı sınır değer olan $20 \mu \mathrm{g} / \mathrm{m}^{3}$ 'e yaklaşmış fakat aşmamıştır. Sınır değere en yakın iller Siirt ve Şanlıurfa'dır. Şanlıurfa'da 2017 yılında araç sayısında azalış söz konusudur. Diğer yıllara göre aracın az olması $\mathrm{SO}_{2}$ değerinin de azalmasına fayda sağlamıştır. $\mathrm{SO}_{2}$ miktarının en az ölçüldüğü sahalar ise Şırnak ve Adıyaman'dır. Şırnak'ta $\mathrm{SO}_{2}$ değerinin az olması sanayide kullanılan yakıtın azaltılması ile yakından ilgilidir. Adıyaman'da ise önceki yıllarda olduğu gibi topografik etkilere bağlı olarak kirliliğin yoğunluğu ve şiddeti az görülmektedir. Bu manada Adıyaman ili 2017 yılında yıllık SO 2 miktarı bakımından bölgede en temiz iller arasında yer almaktadır (Şekil 9). 


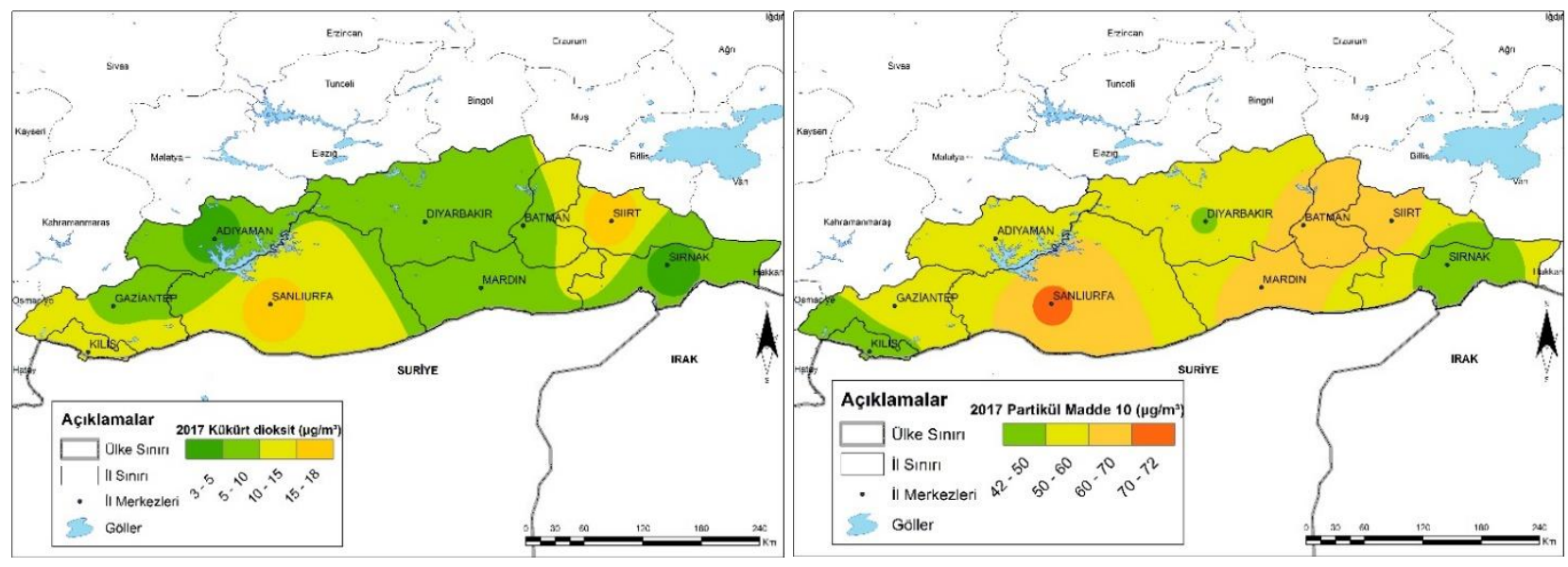

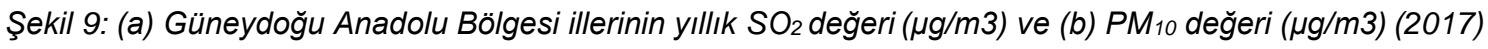

Şekil 9 incelendiğinde, 2017'de $\mathrm{PM}_{10}$ miktarında sınır değerin aşıldığ görülmekle birlikte Şanlıurfa ve Siirt’te partikül madde miktarının arttığı görülmektedir. Özellikle Şanlıurfa'da sınır değerin 2 katı şeklinde kirlenme görülmektedir. Yaklaşık olarak $80 \mu \mathrm{g} / \mathrm{m}^{3}$ olarak hesaplanmıştır. Siirt'te ise yaklaşık olarak $70 \mu \mathrm{g} / \mathrm{m}^{3}$ olarak hesaplanmıştır. Bu kapsamda özellikle kirliliğin oluşmasında; yakın çevrede bulunan çöllerden gelen toz parçacıkları ile yakıt tüketiminin artması en temel etken olarak görülmektedir.

Şekil 10 incelendiğinde, 2019'da $\mathrm{SO}_{2}$ miktarında Şanlıurfa'da en yüksek seviye görülmektedir. Bu seviye yaklaşık olarak $35 \mu \mathrm{g} / \mathrm{m}^{3}$ 'dür. Kirliliğin en az olduğu sahalar ise Diyarbakır, Batman ve Gaziantep'in bir bölümü ile Kilis ilidir. $\mathrm{PM}_{10}$ kirleticisinde ise, bu dönemde Şırnak’ta sınır değerin 2 katı seviyede olduğu görülmüştür. Sınır değer Kilis, Gaziantep'in güneybatısı, Adıyaman, Şanlıurfa'nın batısı ve kuzeybatısı ile Batman'ın büyük bölümünde aşılmıştır.

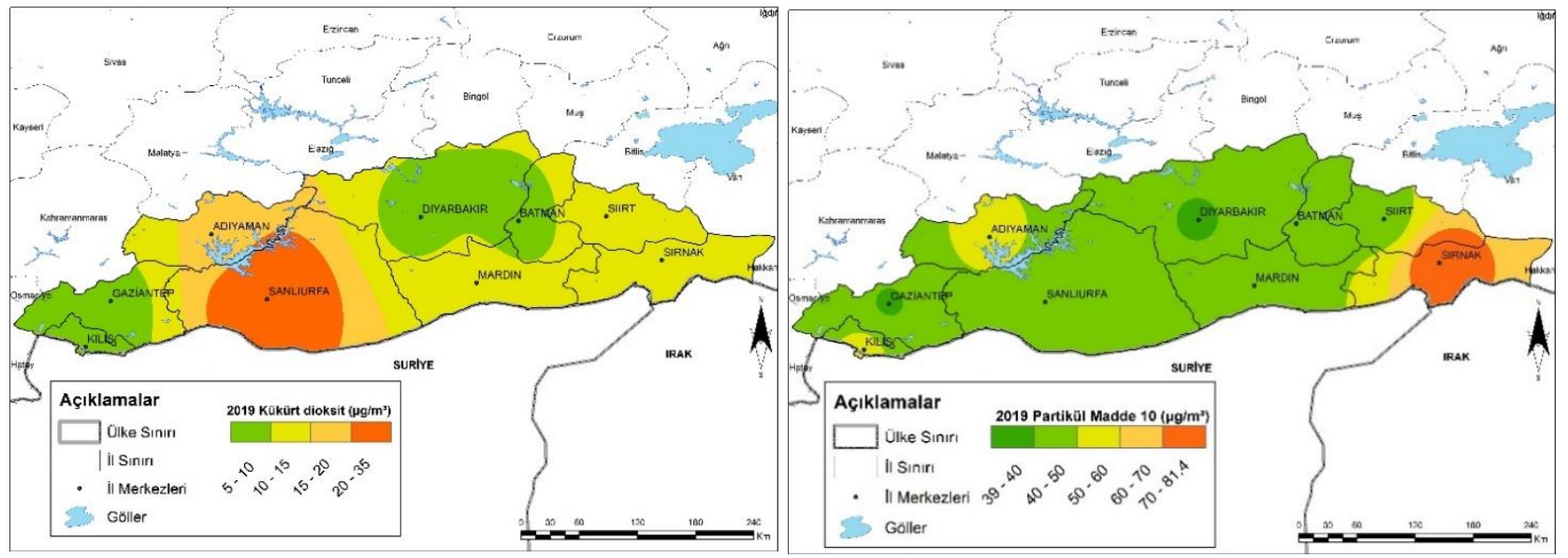

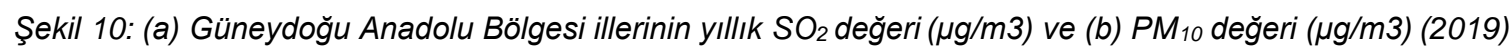

İnsanlar, farklı hava kirleticileri ile olumsuz etkilere daha çok solunum ve besin yoluyla maruz kalırken, deri yolu ile bu etkilere maruz kalma daha azdır (Kaya ve Öztürk 2013). Bu nedenle SO2, $\mathbf{P M}_{10}-\mathbf{P M}_{2,5}$, Karbon monoksit gibi kirleticilere uzun süre ve yoğun bir şekilde maruz kalma, insan sağlığına olumsuz etkiler bırakmakta hatta ölümlere bile yol açmaktadır. Bu bakımdan tablo 2 incelendiğinde, Güneydoğu Anadolu Bölgesi illerinin 2009'dan 2018'a kadar olan süreçteki solunum hastalıklarına bağlı ölümlerin miktarında tüm illerde artış görülmüştür. Miktar bakımından solunum hastalıklarına bağlı ölümlerin en fazla görüldüğü yer Gaziantep'tir.

Onu sırasıyla Şanlıurfa, Diyarbakır ve Adıyaman takip etmektedir. Güneydoğu Anadolu Bölgesi illerinde 2009-2018 yılları arasında solunum hastalıklarına bağlı 21.791 ölüm meydana gelmiştir. Solunuma bağlı ölümlerin nüfusa oranlanması sonucunda Kilis başta olmak üzere Adıyaman ve Gaziantep’te ölüm oranlarının fazla olduğu görülmektedir. Bölgede 2009'dan 2018'e kadar olan süreçte solunum hastalıklarına bağlı ölüm oranları Kilis’te \% 0,60, Adıyaman'da \% 0,38 ve Gaziantep'te de \% 0,32'dir (Şekil 11). 
Tablo 2: Güneydoğu Bölgesi illerinde solunum hastalığına bağlı ölümler (TÜIK 2020b)

\begin{tabular}{|c|c|c|c|c|c|c|c|c|c|}
\hline Yillar & Gaziantep & Adıyaman & Kilis & Şanlıurfa & Diyarbakır & Mardin & Batman & Şırnak & Siirt \\
\hline 2009 & 353 & 112 & 61 & 272 & 221 & 115 & 68 & 59 & 59 \\
\hline 2010 & 440 & 131 & 54 & 257 & 218 & 103 & 78 & 63 & 58 \\
\hline 2011 & 570 & 167 & 81 & 350 & 269 & 165 & 98 & 82 & 65 \\
\hline 2012 & 526 & 161 & 66 & 325 & 271 & 129 & 118 & 74 & 60 \\
\hline 2013 & 639 & 235 & 100 & 507 & 324 & 177 & 129 & 83 & 63 \\
\hline 2014 & 604 & 236 & 82 & 512 & 367 & 265 & 158 & 98 & 80 \\
\hline 2015 & 646 & 242 & 65 & 452 & 365 & 229 & 137 & 102 & 92 \\
\hline 2016 & 750 & 332 & 91 & 594 & 496 & 330 & 188 & 147 & 108 \\
\hline 2017 & 709 & 317 & 92 & 519 & 478 & 242 & 133 & 102 & 102 \\
\hline 2018 & 720 & 324 & 84 & 464 & 495 & 296 & 151 & 141 & 98 \\
\hline Toplam & 5.957 & 2.257 & 776 & 4.252 & 3.504 & 2.051 & 1.258 & 951 & 785 \\
\hline G.Toplam & \multicolumn{9}{|c|}{21.791} \\
\hline
\end{tabular}

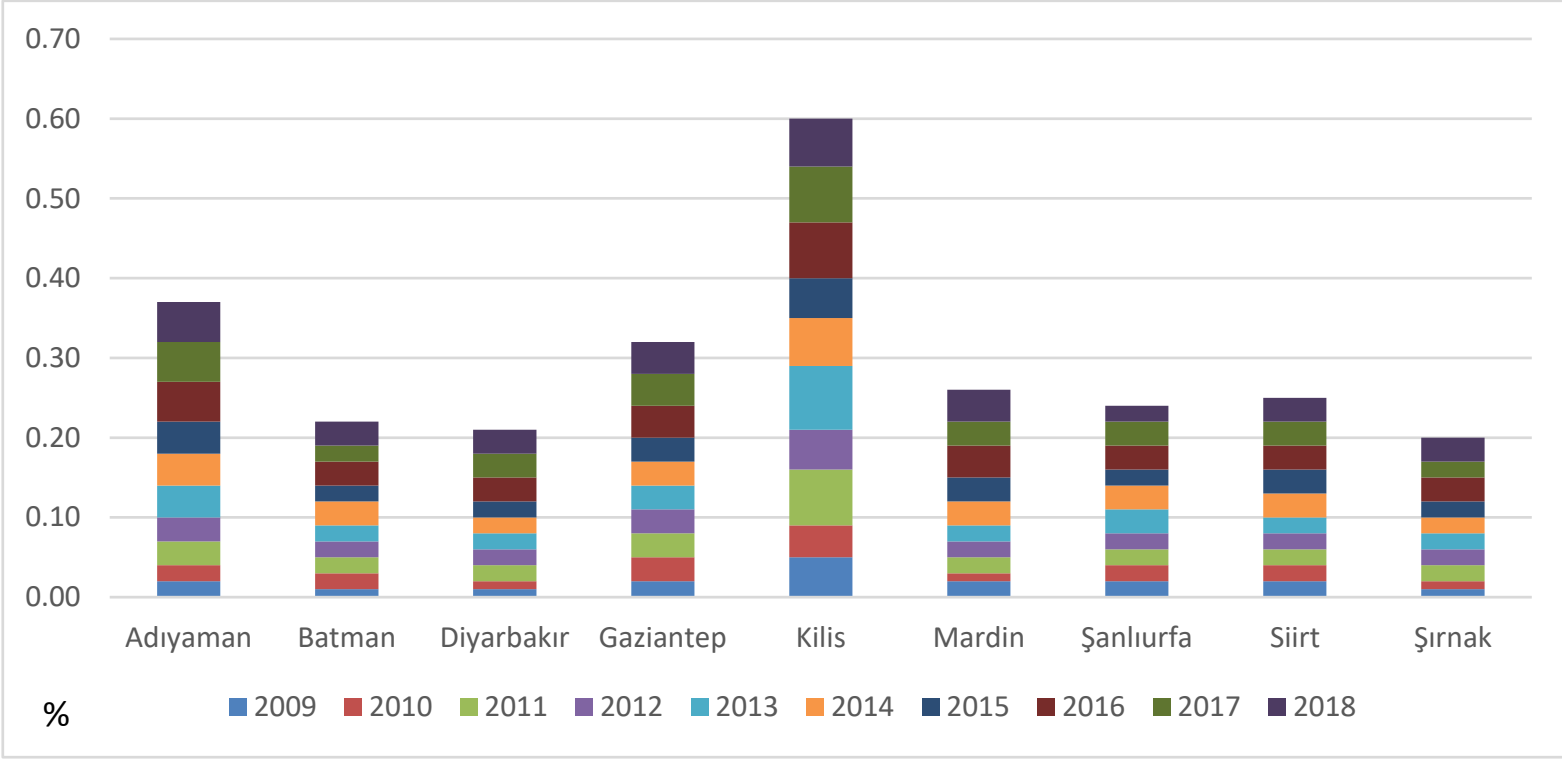

Şekil 11: Güneydoğu Bölgesi illerinde solunum hastalığına bağıı̈lümlerin oransal dağılımı (2009-2018)

\section{Tartışma ve Sonuç}

Güneydoğu Anadolu Bölgesi illerinin 2007-2019 yılları arasındaki hava kirliliği ve önemli etkenleri incelendiğinde, özellikle Gaziantep, Şanlıurfa, Diyarbakır, Siirt ve Batman'da kirlilik seviyesinin yüksek olduğu görülmektedir. Görülen bu kirliliğin ısınma kaynaklı olduğu ve ayrıca kullanılan yakıtın kalitesi, türü ve miktarıyla da yakından ilişkili olduğu görülmektedir. Ayrıca illerin bulunduğu topografik yapı da kirliliğin yoğunluk ve şiddetinin artmasına veya azalmasına etki etmektedir.

Bölgede incelenen yıllarda $\mathrm{SO}_{2}$ ve $\mathrm{PM}_{10}$ konsantrasyonlarında sınır değerlerin aşıldığı görülmektedir. Sadece 2017'de bölgedeki $\mathrm{SO}_{2}$ konsantrasyonun sınır değeri aşmadığı görülmüştür. Fakat bu değer yıllık ortalama baz alınarak hesaplanmıştır. SO $\mathrm{SO}_{2}$ konsantrasyonunda 2007'de Siirt ve Şanlıurfa, 2012'de Şırnak, 2017'de Siirt ve Şanlıurfa ve 2019'da da Şanlıurfa kirlilik seviyesinin yüksek olduğu illerdir. $\mathrm{PM}_{10}$ konsantrasyonunda da 2007'de Batman, 2012'de Gaziantep, Batman ve Siirt, 2017'de Şanlıurfa, Siirt ve Mardin çevresinde, 2019'da da Şırnak ve çevresinde kirlilik seviyesinin yüksek olduğu görülmektedir.

Bölgedeki illerde şehir nüfusunun kır nüfusuna göre fazla olması ve her yıl nüfus yoğunluğunun artması, konutlarda 1sınma amacıyla daha fazla yakıt kullanımına neden olmaktadır. Konutlarda yakıt türünün büyük ölçüde kömür olması, kömürün kalitesinin düşük olması, sanayide üretim için kömürün ve fuel oilin kullanılması, sanayiye bağlı işletme sayılarının artması ve araç sayısının artması sonucunda bölgedeki illerde hava kirliliği yoğun olarak görülmektedir. Ayrıca bölgede hava kirliliğinin yaşanmasına etki eden beşerî unsurların yanı sıra bölgeye yakın olan çöllerden toz parçacıkları da gelmektedir. Bu da belli dönemlerde ciddi hava kirliliğine neden olmaktadır. Hava kirliliği insanlarda önemli solunum hastalıklarına yol açan en temel etkenlerin başında gelmektedir. Bölgede 2008'den 2019'a kadar olan sürede yaklaşık olarak 22.000 kişi solunum rahatsızlığına bağlı olarak hayatını kaybetmiştir. Bu hastalıklara ve ölümlere hava kirliliği de önemli miktarda etki etmiş/etmektedir. Bu nedenle hem insanların hem bitki ve hayvanların hem de beşerî yapıların olumsuz etkilenmemesi için yerel ve ulusal yönetimlerin bu konu hakkında büyük oranda önlem ve yaptırımların uygulanması hayati önem taşımaktadır. 
İllerin hava kalitesi verilerinin toplanmasında Çevre ve Şehircilik Bakanlığına bağlı otomatik ölçüm istasyonları kullanılmaktadır. Bu ölçüm istasyonlarında ciddi ve büyük oranda veri kayıpları görülebilmektedir. Bu veri kayıplarının minimum seviyeye indirilmesi gerekmektedir. Ayrıca Güneydoğu Anadolu Bölgesindeki illerde ilgili bakanlığa bağlı tek ölçüm istasyonu bulunmaktadır. İllerde tek ölçüm istasyonun bulunması o sahanın hava kirliliğinin daha doğru ve sağlıklı okunması ve haritalandırılabilmesini zorlaştırmaktadır. Bu nedenle illerde farklı lokasyonlar da çoklu ölçüm yapılması gerekmektedir. Ayrıca gezici hava kirliliği ölçen araçların yanı sıra illerdeki mevcut ölçüm istasyon sayılarının arttırılarak ilin geneline dağıtılması kirliliğin şiddetinin ve yoğunluğunun ölçülmesinde daha doğru kararların alınmasını sağlayacaktır.

Bölgede çölden gelen toz parçacıkları önemli akciğer sorunlarına neden olabilmektedir. Bu nedenle Suriye, Irak ve İran üzerinden gelen çöl tozlarının insan sağlığını daha az etkilenmesi için yerel yönetimlerin bölge insanına maske gibi koruyucu malzeme vermesi insanların sağlığının daha az etkilenmesine fayda sağlayacaktır. Toz parçacıkları çamur yağışlarına da neden olmaktadır. Çamur yağışları da beşerî unsurlara (araç, tarihi ve kültürel yapı, bina dış yüzeyi vb.), bitki örtüsüne ve tarım ürünlerine zarar verebilmektedir.

\section{Kaynaklar}

Adıg̈zel F., Çetin M., Kaya E., Şimşek M., Güngör Ş., Sert Bozdoğan E., (2019), Defining suitable areas for bioclimatik comfort for landscape planning and landscape management in Hatay, Turkey, Theoretical and Applied Climatolgy, 139, 1493-1503.

Alkan A., (2018), Hava kirliliğinin ciddi boyutlara ulaştığı kentlere bir örnek: Siirt, Bitlis Eren Üniversitesi Sosyal Bilimler Enstitüsü Dergisi, 7, 641-666.

Atayeter Y., (2005), Burdur şehrinde hava kirliliği üzerine bir değerlendirme, I. Burdur Sempozyumu, 16-19 Kasım, ss.635-644.

Batan M., (2013), Batman ilinde kirletici emisyonlardan kaynaklanan hava kirliliğinin küresel lsınmaya etkisi, Batman Üniversitesi Yaşam Bilimleri Dergisi, 3(2), 90-104.

Bayat B., (2011), Hava kirliliği ve kontrolü, Bilim ve Akın Aydınlığında Eğitim, 135, 55-59.

Cuci Y., Polat E.E., (2015), Gaziantep'in trafik kaynakl hava kirliliğinin belirlenmesi, KSU Mühendislik Bilimleri Dergisi, 18(2), 111.

Çiçek İ., Türkoğlu N., Gürgen G., (2004), Ankara'da hava kirliliğinin istatistiksel analizi, Fırat Üniversitesi Sosyal Bilimler Dergisi, 14(2), 1-18.

Çiftçi Ç., Dursun Ş., Levend S., Kunt F., (2013), Topoğrafik yapı, iklim şartları ve kentleşmenin Konya'da hava kirliliğine etkisi, European Journal of Science and Technology, 1(1), 19-24.

ÇMO, (2019), Dünya çevre günü basın metni, TMMOB Çevre Mühendisleri Odası, http://www.cmo.org.tr/genel/bizden_detay.php ?kod= 99799\& \&ipi=67\&sube $=16$ [Erişim 28 Mart 2020].

ÇŞB, (2020), Il çevre durum raporları, T.C. Çevre ve Şehircilik Bakanlı̆̆ı, Çevresel Etki Değerlendirmesi, İzin ve Denetim Genel Müdürlüğü, https://ced.csb.gov.tr/il-cevre-durum-raporlari-i-82671, [Erişim 28 Mart 2020].

Demirarslan K.O., Akıncı H., (2018), CBS ve hava kalitesi verileri kullanılarak Marmara Bölgesi'nin kış sezonunda hava kalitesinin değerlendirilmesi, Doğal Afetler ve Çevre Dergisi, 4(1), 11-27.

Doğan M., (2011), Enerji kullanımının coğrafi çevre üzerindeki etkileri, Marmara Coğrafya Dergisi, 23, 36-52.

Dündar C., Oğuz K., Güllü G., (2013), Doğu Akdeniz Havzasında Kum ve Toz Fırtınalarının (SDS) Incelenmesi, 10. Ulusal Çevre Mühendisliği Kongresi, 12-14 Eylül, Hacettepe Üniversitesi, Ankara.

ESRI, (2020), How IDW Works, https://desktop.arcgis.com/en/arcmap/10.3/tools/3d-analyst-toolbox/how-idw-works.htm [Erişim 28 Mart 2020].

Garipağaoğlu N., (2003), Türkiye'de hava kirliliği sorununun coğrafi bölgelere göre dağılımı, Doğu Coğrafya Dergisi, 8(9), 55-77.

İbret B.Ü., Aydınözü D., (2009), Şehirleşmede yanlış yer seçiminin hava kirliliği üzerine olan etkisine bir örnek: Kastamonu şehri, İstanbul Üniversitesi Edebiyat Fakültesi Coğrafya Bölümü Coğrafya Dergisi, 18, 71-88.

Kaya D., Öztürk H.H., (2013), Hava Kalitesi ve Yönetimi, Umuttepe Yayınları, Kocaeli, 334ss.

Özbey B.G., Geven F., Güney K., Bölükbaşı A., Günday B., (2017), Güneydoğu Anadolu Bölgesi’nin hava kalitesi analizi (Mayls 2016-2017), Ankara üniversitesi Çevre Bilimleri Dergisi, 5(2), 50-64.

Özbeyaz A., Tufaner F., Demirci Y., (2016), Partikül madde ile ilişkili görüntüleri kullanarak hava kirliliği tahminine ait bir model tasarımı, 1st International Mediterranean Science and Engineering Congress, October 26-28, Adana, Turkey, ss.969-975.

Özşahin E., Eroğlu İ., Pektezel H., (2016), Keşan'da (Edirne) hava kirliliği, Selçuk üniversitesi Sosyal Bilimler Enstitüsü Dergisi, 36 , 83-100.

Sertkaya Doğan Ö., (2015), Population movements in Turkey: international migrations, International Journal of Liberal Arts and Social Science 3, 102-110.

STB, (2020), 81 Il Sanayi Durum Raporları (2009-2017), T.C. Sanayi ve Teknoloji Bakanlığı, https://www.sanayi.gov.tr/planprogram-raporlar-ve-yayinlar/81-il-sanayi-durum-raporlari, [Erişim 28 Mart 2020].

Sümer Çakır G., (2014), Hava Kirliliği Kontrolü: Türkiye'de Hava Kirliliğini Önlemeye Yönelik Yasal Düzenlemelerin ve Örgütlenmelerin İncelenmesi, Uluslararası İktisadi ve İdari İncelemeler Dergisi, 13, 37-56.

Şengün M.T., Kıranşan K., (2012), Güneydoğu Anadolu Bölgesi'nde çöl tozlarının hava kalitesi üzerine etkisi, Türk Coğrafya Dergisi, $59,59-68$.

Tağıl Ş., (2007), Balıkesir'de hava kirliliğinin solunum yolu hastalıklarının mekânsal dağıllşı üzerine etkisini anlamada jeo-istatistik teknikler, Coğrafi Bilimler Dergisi, 5(1), 37-56.

Toros H., Bağış S., Gemici Z., (2018), Ankara'da hava kirliliği mekânsal dağılımının modellenmesi, Ulusal Çevre Bilimleri Araştırma Dergisi, Sayı 1(1), 20-53.

TÜIK, (2020a), Genel Nüfus Sayımları, https://data.tuik.gov.tr/Kategori/GetKategori?p=Nufus-ve-Demografi-109, [Erişim 28 Mart 2020]. 
TÜİK, (2020b), Ölüm ve ölüm nedenleri istatistikleri (2009-2018), https://data.tuik.gov.tr/Bulten/Index?p=Olum-ve-Olum-NedeniIstatistikleri-2019-33710, [Erişim 28 Mart 2020].

Vural E., (2019), Viranşehir (Şanlıurfa) şehir merkezindeki trafik kazalarının coğrafi analizi (2013-2017), Kent Akademisi, 12(38), 340-363. 